\title{
PELATIHAN PENELITIAN TINDAKAN KELAS UNTUK MENINGKATKAN PROFESIONALISME GURU SD DI KECAMATAN BULELENG
}

\author{
Ni Ketut Rapi 1,*, Iwan Suswandi ${ }^{2}$, I G. A. Nyoman Sri Wahyuni ${ }^{3}$ \\ 1 Jurusan Pendidikan Fisika. Universitas Pendidikan Ganesha, Indonesia \\ 2Jurusan Pendidikan Matematika. Universitas Pendidikan Ganesha, Indonesia \\ 3Jurusan Pendidikan Ilmu Pengetahuan Alam. Universitas Pendidikan Ganesha, Indonesia
}

\begin{abstract}
Abstrak
Guru Tujuan kegiatan pengabdian kepada masyarakat ini adalah untuk meningkatkan pengetahuan tentang penelitian tindakan kelas (PTK) bagi guru-guru SD di Kecamata Buleleng. Sasaran kegiatan ini adalah guru-guru SD yang ada di Kecamatan Buleleng sebanyak 20 orang. Metode kegiatan dilakukan dengan memberikan ceramah, tanya jawab, pelatihan membuat proposal PTK, dan pendampingan di Sekolah. Kegiatan bertempat di ruang PPG Jurusan Pendidikan Fisika FMIPA Undiksha. Hasil pelatihan menunjukkan bahwa secara umum pelaksanaan kegiatan berjalan dengan baik. Kegiatan pelatihan dapat meningkatkan pengetahuan para peserta tentang PTK hal ini didasarkan pada draf proposal yang dihasilkan oleh peserta. Respon peserta sangat positif, guru-guru sangat antusias mengikuti pelatihan. Para peserta sangat mengharapkan kegiatan ini berkelanjutan.
\end{abstract}

Keywords:

pelatihan, Penelitian

Tindakan Kelas

\section{Pendahuluan}

Semenjak disahkannya UUGD (Undang-Undang Guru dan Dosen) pada bulan Desember 2005, istilah sertifikasi khususnya sertifikasi guru menjadi sangat populer. Hampir dalam setiap pertemuan/seminar/diskusi yang diikuti oleh guru, masalah sertifikasi selalu menjadi topik yang hangat. Hal ini dapat dimengerti karena menurut pasal 16 UUGD, dinyatakan bahwa guru yang memiliki sertifikat pendidik berhak mendapatkan tunjangan profesi sebesar $1 \mathrm{x}$ gaji. Apalagi, tunjangan profesi tersebut diberikan kepada guru negeri maupun swasta, selama yang bersangkutan memiliki sertifikat pendidik. Jadi sangat wajar jika ada orang yang mengatakan bahwa UUGD seakan menjadi "angin sorga" bagi guru di Indonesia. Undang-Undang RI Nomor 20 Tahun 2003 tentang Sistem Pendidikan, Undang-Undang RI Nomor 14 Tahun 2005 tentang guru dan dosen, Peraturan Pemerintah Nomor 19 Tahun 2005 tentang Standar Nasional Pendidikan, dan Peraturan Peraturan Pemerintah Nomor 74 Tahun 2008, mulai tahun 2009 sertifikasi guru dalam jabatan juga menyertakan guru yang diangkat dalam jabatan pengawas satuan pendidikan.

Mulai tahun 2010 Sertifikasi bagi guru dalam jabatan dilakukan melalui PLPG, dan mulai tahun 2011 dilakukan melalui PLPG dan PPG. Peraturan Pemerintah tersebut mengamanatkan bahwa guru wajib memiliki kualifikasi akademik, kompetensi, sertifikat pendidik, sehat jasmani dan rohani, serta memiliki kemampuan untuk mewujudkan tujuan pendidikan nasional. Persyaratan kualifikasi akademik guru adalah S1/DIV yang dibuktikan dengan ijasah sesuai dengan jenis, jenjang, dan satuan pendidikan formal di tempat penugasan. Persyaratan kompetensi guru mencakup penguasaan kompotensi pedagogik, profesional, kepribadian, dan sosial yang dibuktikan dengan sertifikat pendidik yang diperoleh melalui sertifikasi. Peraturan Menteri Pendidikan Nasional (Permendiknas) Nomor 18 Tahun 2007 menyatakan bahwa sertifikasi bagi guru dalam jabatan dilaksanakan melalui uji kompetensi untuk memperoleh sertifikan pendidik (Depdiknas dan Ditjendikti: 2007).

Uji kompetensi tersebut dilakukan dalam bentuk PPG. Berdasarkan data yang ada di Dinas Pendidikan Kabupaten Buleleng, saat ini Dinas Kabupaten Buleleng sudah merekrut guru SD sebanyak 931 orang dengan kualifikasi akademik D2 PGSLP, D3 dan sebagian sudah sarjana. Untuk mencapai kualifikasi yang diamanatkan Peraturan Pemerintah Nomor 19 Tahun 2005 dan meningkatkan profesionalisme guru, pemerintah Kabupaten Buleleng telah memberikan kesempatan kepada para 
gurum untuk melanjutkan studi baik dengan sistem penyetaraan maupun reguler. Sementara untuk melaksanaan Peraturan Menteri Pendidikan Nasional No. 18 Tahun 2007, pemerintah kabupaten Buleleng melalui Dinas Pendidikan Kabupaten telah melakukan sosialisasi mekanisme dan prosedur sertifikasi kepada guru.

Hasil wawancara dengan beberapa guru SD di Kabupaten Buleleng, diperoleh informasi bahwa sebagian besar dari mereka kepangkatannya mentok pada golongan IVa. Hal ini disebabkan, untuk mengusulkan ke golongan IVb harus dilengkapi dengan bukti karya ilmiah, berupa penelitian. Disatu sisi guru-guru mengalami kesulitan melakukan kegiatan penelitian karena keterbatasan mereka dalam pengetahuan tentang PTK. Usaha yang telah dilakukan oleh pemerintah kabupaten Buleleng diantaranya pelatihan penelitian Tindakan kelas, namun hasil wawancara dengan beberapa guru SD di kecamatan Buleleng menunjukkan masih banyak guru mempunyai pengetahuan dan keterampilan yang kurang tentang Penelitian Tindakan Kelas. Para guru sangat membutuhkan pelatihan tentang Penelitian Tindakan Kelas. Melihat kenyataan yang diuraikan di atas, nampaknya perlu dilakukan suatu kegiatan yang mampu meningkatkan pemahaman dan keterampilan para guru dalam bidang karya pengembangan profesi, khususnya PTK.

Hal ini dilakukan melalui kegiatan pengabdian kepada masyarakat (P2M) sebagai salah satu kegiatan Tri Dharma Perguruan Tinggi. Khalayak yang menjadi sasaran kegiatan ini adalah para guru SD di Kecamatan Buleleng. Kegiatan ini berupa pelatihan PTK dengan menekankan pada penguasaan terhadap teori dan Praktek PTK. Berdasarkan hasil survai oleh tim pelaksana, diperoleh gambaran bahwa salah satu permasalahan yang saat ini dihadapi oleh Dinas Pendidikan dan Kebudayaan Kabupaten Buleleng adalah terbatasnya dana untuk melaksanakan pelatihan bagi para guru. Di sisi lain, kualitas dan profesionalitas guru-guru SD yang ada di Kabupaten Buleleng khususnya dalam melakukan penelitian tindakan kelas masih kurang. Disamping itu banyak guru yang masih kurang memahami tentang modelmodel pembelajaran inovatif, system asesmen dan mengembangkan buku ajar. Hal ini juga terjadi pada para guru yang bertugas di Kecamatan Buleleng. Hal ini akan berdampak pada usulan naik pangkat, karena salah satu komponen yang harus dimiliki oleh guru untuk mengusulkan naik pangkat ke golongan IVb adalah karya ilmiah yang berupa laporan hasil penelitian.

Sebagian besar guru-guru mentok di golongan IVa karena tidak bisa melakukan kegiatan ilmiah (penelitian). Mencermati hal di atas perlu kiranya dilakukan pembekalan berupa kegiatan pelatihan tentang pengatahuan dan keterampilan PTK bagi guru-guru SD di Kabupaten Buleleng, khususnya guruguru SD di Kecamatan Buleleng agar guru-guru memiliki pengetahuan dan keterampilan dalam melakukan PTK. Lebih lanjut diharapkan dengan pengetahuan dan keterampilan yang dimiliki para guru mampu melakukan PTK, mampu memperbaiki proses pembelajaran, dan bisa mengusulkan naik pangkat kejenjeng yang lebih tinggi. Secara singkat PTK dapat didefinisikan sebagai suatu bentuk kajian yang bersifat reflektif oleh pelaku tindakan yang dilakukan untuk meningkatkan kemantapan rasional dari tindakan-tindakan mereka dalam melakukan tugas, memperdala pemahaman terhadap tindakan-tindakan yang dilakukannya itu, serta memperbaiki kondisi di mana praktekpraktek pembelajaran tersebut dilakukan. Untuk mewujudkan tujuantujuan tersebut, PTK dilaksanakan berupa proses pengkajian berdaur yang terdiri dari 4 tahap yakni: merencanakan, melakukan tindakan, mengamati, dan merefleksi. Tujuan utama PTK adalah untuk memecahkan permasalahan nyata yang terjadi di dalam kelas.

PTK dilaksanakan demi perbaikan dan/atau peningkatan praktek pembelajaran secara berkesinambungan yang pada dasarnya melekat pada penunaian misi professional kependidikan yang diemban oleh guru. PTK merupakan salah satu cara yang strategis bagi guru untuk memperbaiki dan/atau meningkatkan layanan kependidikan yang harus diselenggarakannya dalam konteks pembelajaran di kelas. MCNiff (1992) menegaskan bahwa dasar utama bagi dilaksanakan PTK adalah untuk perbaikan proses pembelajaran khususnya, implementasi program sekolah umumnya. Jika perbaikan dan peningkatan layanan profesional guru dalam konteks pembelajaran dapat terwujud berkat diadakannya PTK, ada tujuan penyerta yang juga dapat dicapai sekaligus dalam penelitian itu, yakni tumbuhnya budaya meneliti di kalangan guru.

Hopkins (1993) menyebutkan 6 prinsip penting yang mesti diperhatikan bila guru melaksanakan penelitian tindakan kelas sebagai berikut. (a) Pekerjaan utama guru adalah mengajar, maka pelaksanaan penelitian yang dilakukan tidak boleh mengganggu atau menghambat kegiatan pembelajaran. (b) Teknik pengumpulan data jangan sampai banyak menyita waktu, sehingga tugas utama guru tidak terbengkalai. (c) Metodologi yang digunakan cukup reliabel, yang memungkinkan guru merumuskan hipotesis dengan meyakinkan dan mengembangkan strategi yang sesuai dengan masalah dan kondisi kelasnya. (d) Masalah yang diangkat hendaknya merupakan masalah yang dihadapi guru sendiri dan benar-benar merupakan masalah yang dapat dipecahkan melalui PTK oleh guru itu sendiri. (e) Harus memperhatikan etika penelitian dan rambu-rambu yang berlaku umum seperti, yang diteliti harus dihormati kerahasiaannya, membuat laporan hasil dan sebagainya. (f) Kegiatan penelitian pada dasarnya harus merupakan gerakan 
yang berkelanjutan karena cakupan peningkatan dan pengembangan sepanjang waktu menjadi tantangan. Bertumbuhnya budaya meneliti yang merupakan dampak bawaan dari pelaksanaan PTK secara berkesinambungan, maka banyak kemanfaatan yang dapat dipetik yang secara keseluruhan dapat diberi label inovasi pendidikan karena para guru itu semakin diberdayakan untuk mengambil berbagai prakarsa profesional secara semakin mandiri.

Sebagaimana dikemukakan oleh Rapoport (dalam Tim pelatihan proyek PGSM, 1999), penelitian tindakan kelas bertolak dari kepedulian terhadap pemecahan persoalan-persoalan praktis yang dihadapi oleh manusia dalam pekerjaannya sehari-hari. Dalam pada itu, hanya inovasi yang tumbuh dari bawah seperti inilah yang benar-benar berangkat dari realitas permasalahan yang dihayati oleh guru di kelas dan/atau di sekolah, bukan yang diinstruksikan dari atas. Untuk melakukan PTK, guru perlu melakukan langkah-langkah berikut ini: (1) Identifikasi permasalahan PTK, (2) Menganalisis masalah dan merumuskan masalah untuk keperluan PTK, (3) Merencanakan tindakan perbaikan berdasarkan contoh rumusan masalah yang diajukan, (4) Memahami tahap pelaksanaan tindakan dan cara observasiinterpretasi yang dilakukan sementara PTK berlangsung, (5) Memahami cara menganalisis data hasil observasi serta melakukan refleksi berkenaan dengan tindakan perbaikan yang dilaksanakan, (6) Memahami cara merencanakan tindak lanjut dalam siklus dalam PTK Secara lebih rinci, prosedur berdaur pelaksanaan PTK itu dapat digambarkan sebagai berikut.

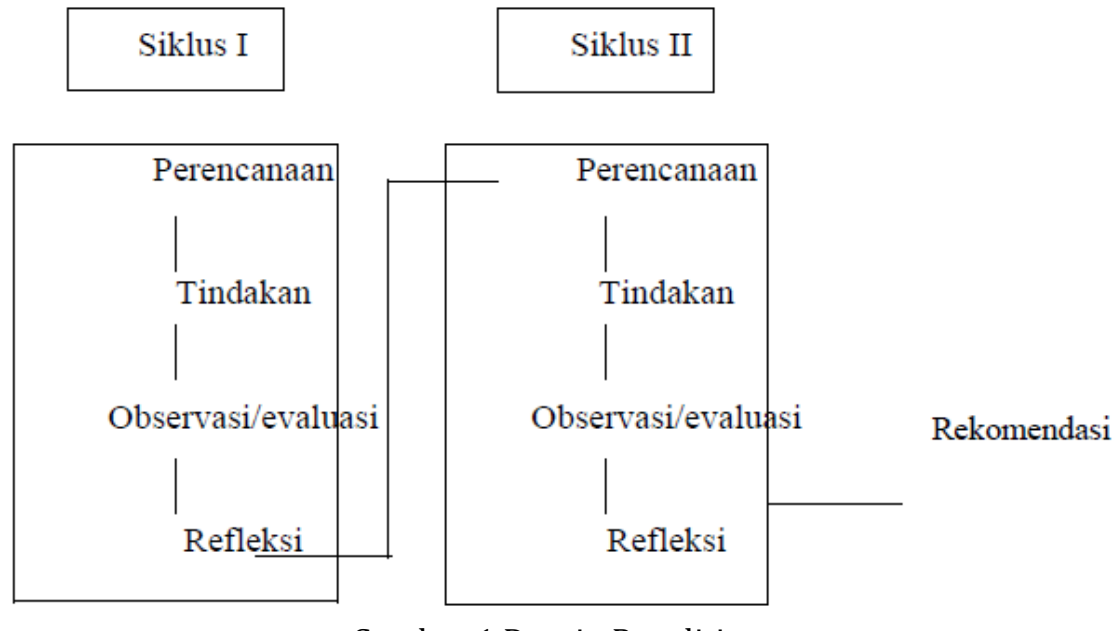

Gambar 1 Desain Penelitian

Berdasarkan identifikasi masalah di atas, maka masalah pokok yang akan dipecahkan melalui kegiatan P2M ini adalah“ Bagaimana memberikan pengetahuan dan keterampilan PTK, sehingga para guru mempunyai kompetensi untuk merancang dan mengimplementasikan PTK. Sejalan dengan rumusan masalah di atas, maka tujuan utama dari kegiatan ini adalah meningkatkan pengetahuan dan keterampilan guru tentang Penelitian Tindakan Kelas.

\section{Metode}

Masalah yang ada di lapangan kemudian diidentifikasi sehingga ditemukan ada masalah yang perlu mendapatkan penanganan segera, yaitu guru kurang memahami PTK, yang merupakan salah satu faktor penghambat untuk pengusulan naik pangkat. Setelah itu dilakukan pengkajian pustaka, ditemukan alternatif untuk pemecahan masalah yaitu melalui pelatihan PTK untuk meningkatkan pengetahuan dan kemampuan guru melakukan PTK. Agar para peserta pelatihan memiliki pemahaman yang memadai tentang bagaimana melakukan Penelitian Tindakan Kelas, maka metode yang dipilih untuk mencapai tujuan ini adalah presentasi dari fasilitator yang dilanjutkan dengan tanya jawab, diskusi dan latihan penyusunan proposal PTK.

Selanjutnya, agar para peserta memiliki kemampuan dan keterampilan melakukan Penelitian Tidakan Kelas, maka langkah selanjutnya adalah: (1) memberikancontoh mimplementasi Penelitian Tindakan Kelas, (2) latihan merancang Penelitian Tindakan Kelas, (3) mempresentasikan hasil latihan, dan pendampingan di Sekolah. Untuk mengetahui tercapainya tujuan dari kegiatan ini, dilakukan evaluasi pada akhir kegiatan. Indikator yang digunakan sebagai kriteria keberhasilan program ini adalah kemampuan merancang proposal PTK, dinilai dari hasil rancangan Penelitian Tindakan Kelas yang dihasilkan peserta. 


\section{Hasil Dan Pembahasan}

Pelatihan penelitian tindakan kelas bagi guru-guru SD di kecamatan Buleleng ini, dilaksanakan pada tanggal 1 dan 2 Agustus 2016. Kegiatan dimulai pukul 08.30 dan berakhir pukul 16.00 WITA. Pelaksana mengundang 20 orang guru dari 10 sekolah di Kecamatan Buleleng melalui kepala sekolah masing-masing. Penunjukan peserta diserahkan kepada kepala sekolah, disarankan guru yang ditunjuk adalah yang mengalami masalah kenaikan pangkat pada komponen karya ilmiah. Dari 20 orang guru yang diundang, ternyata jumlah guru yang hadir sebanyak 15 orang. Ketidak hadiran 5 orang guru disebabkan mereka dapat tugas yang lain pada waktu yang bersamaan, tetapi dari 10 sekolah yang diundang sudah semua terwakili. Hal ini menunjukkan bahwa respon guru-guru atau sekolah terhadap pelaksanaan kegiatan sangat positif. Kemampuan peserta menyusunan proposal PTK, dinilai dari draf proposal yang dihasilkan dalam pelatihan. Berdasarkan hasil analisis data diperoleh nilai rata-rata kemampuan guru dalam menyusun proposal PTK 74 dengan kategori baik.

Berdasarkan capaian di atas, secara umum dapat dikatakan bahwa pelaksanaan pelatihan PTK berjalan dengan baik, memberikan manfaat bagi peserta, dan tepat sasaran. Respon peserta positif, ini terlihat dari peserta sangat antusias mengikuti pelatihan dan banyak muncul pertanyaan saat diskusi. Pertanyaan-pertanyaan yang diajukan peserta diantaranya: 1) Bagaimana cara menemukan masalah dari pembelajaran dari sekolah yang baru menggunakan kurikulum 2013?, 2) Berapa lama waktu ideal untuk melaksanakan PTK?, dan (3) Apakah perbedaan materi pada masing-masing siklus berpengaruh terhadap hasil PTK?. Semua pertanyaan yang diajukan peserta dijawab tuntas oleh Dr. Ni Ketut Rapi, M.Pd selaku Narasumber dan sekaligus sebagai pelaksana P2M. Setelah ceramah dan diskusi dilanjutkan dengan kegiatan latihan penyusunan proposal PTK. Pada awalnya peserta mengalami kesulitan untuk memulai menyusun kalimat, tetapi dengan arahan tim pelaksana kesulitan dapat diatasi. Setelah latihan penyusunan proposal, salah seorang peserta diberi kesempatan untuk mempresentasikan draf proposal yang dihasilkan. Peserta yang lain diberi kesempatan untuk memberi masukan.

Yang menjadi sasaran dalam kegiatan P2M ini adalah Guru-guru SD Di Kecamatan Buleleng sebanyak 20 orang. Lima orang yang menjadi sasaran tidak hadir dalam kegiatan, ini memberikan indikasi bahwa kegiatan semacam ini sangat diperlukan oleh para guru untuk meningkatkan Profesionalisme mereka. Selama mengikuti pelatihan para peserta sangat antusias, ini tercermin dari banyaknya pertanyaan dan permasalah yang diajukan para peserta dalam diskusi. Para peserta sangat serius di dalam diskusi kelompok pada saat latihan membuat proposal PTK, ini terbukti dengan waktu yang relatif singkat setiap kelompok sudah bisa menghasilkan drap proposal yang berkategori baik. Guru sangat menyadari betapa pentingnya mereka mempunyai pengetahuan dan keterampilan tentang Penelitian Tindakan Kelas.

Hasil penelitian tindakan kelas, baik yang belum dipublikasikan (disimpan di perpustakaan) maupun yang telah dipublikasikan dalam jurnal ilmiah dapat digunakan sebagai angka kredit dalam kenaikan pangkat. Hasil penelitian PTK dapat juga dilombakan dalam lomba karya ilmiah. Oleh karena itu instansi terkait perlu memberikan dana bantuan sesuai kemampuan kepada guru-guru untuk memotivasi guru melakukan PTK. Berdasarkan hasil wawancara dengan peserta, beberapa harapan yang disampaikan oleh peserta pelatihan: pertama, frekuensi kegiatan ditambah untuk meningkatkan pengetahuan dan keterampilan tentang PTK, serta dilaksanakan secara berkesinambungan; kedua, Lembaga juga agar mengupayakan sumber pendanaan, sehingga peserta bisa tetap tidak dipungut biaya; ketiga, kegiatan P2M ini juga perlu diberikan kepada guruguru di luar Kecamatan Buleleng; keempat, mohon disediakan waktu pelatihan lebih lama agar dapat melakukan bimbingan penyusunan proposal penelitian lebih intensif, dan guru-guru juga memerlukan pelatihan tentang asesmen.

\section{Simpulan Dan Saran}

Simpulan yang dapat diambil dari hasil kegiatan P2M ini adalah sebagai berikut. 1. Para guru menyadari betapa pentingnya meningkatkan profesionalisme secara berkelanjutan. 2. Pelatihan penelitian tindakan kelas dapat meningkatkan pengetahuan dan keterampilan para peserta tentang PTK. 3. Sebagian peserta sudah menghasilkan proposal PTK yang baik dan siap untuk diimplementasikan 


\section{Daftar Pustaka}

Abimanyu, S. Et al. (1995). Penelitian Praktis untuk Perbaikan Pengajaran. Jakarta: Dikti Depdikbud Departemen Pendidikan Nasioanal dan Direktorat Jenderal.

Pendidikan Tinggi. 2007. Panduan Penyusunan Fortofoli Sertifikasi Guru dalam Jabatan Guru Tahun 2007

Hopkins, D. (1993). A Teacher's Guideto Classroom Research. 2th ed. Buckingham: Open University Press. Pendidikan Nasioanal dan Direktorat Jenderal Pendidikan Tinggi. 2007. Pedoman Sertifikasi Guru dalam Jabatan Guru

Suastra, I.W. 2006. Strategi Menyikapi Undang-Undang Guru dan Dosen. Makalah disajikan pawa Workshop Pengawas se-Kabupaten Buleleng. Tanggal 24 s.d 26 Agustus 2006. Diselenggarakan Diknas Kabupaten Buleleng.

Tim Pelatihan Proyek PGSM. 1999. Penelitian Tindakan Kelas. Jakarta: Depdikbud

Undang-Undang Republik Indonesia No. 14 Tahun 2005 Tentang Guru dan Dosen.

Undang-Undang No.20 Tahun 2003. Tentang Sistem Pendidikan Nasional (Sisdiknas).

Usman,U.M. 2001. Menjadi Guru Profesional. Bandung: Pt. Remaja Rosdakarya. 